\title{
Testing the Effect of the Determinate Shoot Growth Allele on Cucumber Root Growth
}

\author{
Rebecca Grumet ${ }^{1}$ and Robert Duvall ${ }^{2}$ \\ Horticulture Department, Michigan State University, East Lansing, M14 8824
}

Additional index words. Cucumis sativus, herbicide banding technique, plant architecture

\begin{abstract}
The determinate allele (de) of cucumber (Cucumis sativus $\mathbf{L}$.) causes shorter vine length and fewer and shorter internodes and lateral branches than the indeterminate allele (De). Four sets of cucumber inbreds carrying determinate or indeterminate alleles were compared with respect to root growth rate in the field and greenhouse using an herbicide banding method. Although the lines exhibited the expected differences in shoot growth, differences in root growth were not correlated with the differences in shoot growth. These results indicate that root growth was independent of the determinate shoot growth allele.
\end{abstract}

Several cucumber genes, including bush (bu), compact $(c p)$, dwarf $(d w)$, tall height $(T)$,

Received for publication 24 Sept. 1992. Accepted for publication 25 Mar. 1993. We thank Jack Staub and Todd Wehner for kindly providing seed, Gary Winchell and Bill Chase for assistance with the field experiments, Todd Wehner for helpful discussions, and Amy Iezzoni and Jack Kelly for helpful comments on the manuscript. We also thank the Committee for Pickle Research at Michigan State Univ. for their support of this project. Acknowledgment is also made to the Michigan Agricultural Experiment Station for its support of this research. The cost of publishing this paper was defrayed in part by the payment of page charges. Under postal regulations, this paper therefore must be hereby marked advertisement solely to indicate this fact.

'Assistant Professor, to whom reprint requests should be addressed.

Undergraduate student. rosette [ro), little leaf ( $l l$ ), and determinate (de), affect the aboveground architecture of the plant (Pierce and Wehner, 1990). The recessive allele, determinate (de), has been used to develop commercial dwarf cucumber cultivars (Munger, 1985; Prend and John, 1976; Tigchelaar, 1991). The determinate allele also has been described extensively with respect to its effect on aboveground growth characteristics (Delaney and Lower, 1984, 1985, 1987; Denna, 1971; George, 1970; Prend and John, 1976; Wehner and Miller, 1987). Determinate plants have fewer nodes, shorter internode length, fewer and shorter lateral branches, and shorter main stem length than do indeterminate plants $(D e)$. In determinate plants, the terminus of the main axis is converted to floral growth with an attendant termination of main stem growth. Determinate lines also have been associated with more concentrated fruit set. Wehner and Miller (1987) compared the space requirements of several indeterminate and determinate lines and found that optimal yields were obtained at the same planting density for both types. Since increased densities led to a reduction in yield for both vine types, despite differences in vine size, they suggested that root requirements may have been a limiting factor.

Although the determinate allele has a distinct effect on vine growth, it is not known whether root growth also is affected. In fact, little documented information exists concerning below-ground growth traits in genetically related lines that differ in aboveground architecture. In a study using unrelated determinate and indeterminate cotton(Gossypium hirsutum L.) cultivars, Temple (1990) found that the two determinate lines had a lower shoot mass : root mass ratio than did be two indeterminate lines.

In this study, we used the herbicide banding method of Grumet et al. (1992) to examine the effect of the determinate allele on cucumber root growth when expressed in various genetic backgrounds. The herbicide is banded at a specific depth and lateral distance from the seed row. Those plants whose roots grow faster should reach the herbicide band sooner. The herbicide then is translocated to the leaves where damage symptoms become apparent. It is thereby possible to monitor root growth by observing symptoms on the leaves. The root growth of determinate plants was examined in plants with four genetic backgrounds and compared to the response of similar indeterminate genotypes.

Nine cucumber lines were examined. 'Marketmore 76' (De) and 'Marketmore 86' (de) are northern, slicing cucumber cultivars 
that are nearly isogenic with the exception of selection for the determinate allele and earliness (seven backcrosses; Munger, 1985). The determinate allele was transferred from 'Harden's PG57'. Two little-leaf pickling cucumber lines developed by J. Staub (U.S. Dept. of Agriculture, Agricultural Research Service, Madison, Wis.), WI 6373 (De) and WI 6375 (de), are also nearly isogenic (seven backcrosses), with the exception of the determinate allele. Four North Carolina, southern pickling cucumber inbreds also were included: 'Addis' (De); 'Clinton' (De), North Carolina State Univ. (NCSU) M21 (de), and NCSU M27 (de) (Delaney and Lower, 1984, 1987; Ramirez et al., 1988). The NCSU inbreds have several parents in common (i.e., 'Pixie', 'Poinsett', SC19B, 'Tiny Dill', 'Clinton', and 'Chipper'; T. Wehner, personal communication) and are similar but not isogenic. Seed of the NCSU lines were furnished by T. Wehner (NCSU); seed of the little-leaf pair was provided by J. Staub and multiplied in our greenhouse. The Marketmore cultivars were obtained commercially (Stokes Seeds, Buffalo, N.Y.). The commercial pickling cucumber cultivars Flurry and Fancipak (Asgrow Seed Co., Kalamazoo, Mich.) were planted as controls and border rows in the field trials.

Two field experiments were performed in Summer 1991-one in late June and July (planting date 25 June), the second in August and September (planting date 12 Aug.). Although both experiments were performed in the same year, the weather conditions were different. The first experiment occurred when the weather was sunny, dry, and warm (mean 24C); the second one occurred when the weather was cloudier, wetter, and cooler (mean 19C).

Inbreds were arranged in a randomized complete block design with three replications. Each plot was $3 \mathrm{~m}$ long with 1.5 -m borders of a standard cultivar, 'Flurry' (Expt. 1) or 'Fancipak' (Expt. 2), on both ends. Rows with the nine inbreds alternated with rows of 'Flurry' or 'Fancipak'. The external border rows were 'Flurry' or 'Fancipak'. The rows were $1.5 \mathrm{~m}$ apart; plants were thinned to $10-\mathrm{cm}$ intervals within the row. The soil type was Marlette fine sandy loam (mesic Glossoboric Hapludalfs). About $25 \mathrm{~mm}$ water/week was applied via rain or supplemental irrigation.

Application of the herbicide bands was essentially as described by Grumet et al. ( 1992). Bands of 6-chloro-N,N'-diethyl-1 ,3,5-triazine2,4-diamine (Simazine; CIBA<EIGY Corp., Greensboro, N. C.) at $1.5 \mathrm{~kg}$ a.i./ha were placed on each side of the seed row at a depth of $15 \mathrm{~cm}$ and a lateral distance of $36 \mathrm{~cm}$ (to the center of the band) using a subsurface applicator; the spray band was $30 \mathrm{~cm}$ wide. Plants in the center $3 \mathrm{~m}$ of each plot were monitored daily for appearance of herbicide-induced symptoms. Symptoms were rated on a $\mathrm{O}$ to 3 scale as per Grumet et al. (1992): $0=$ leaves healthy and dark green; 1 = pale leaves; $2=$ white or gray ring around edge of leaves, or white patches; and $3=$ necrotic lesions on leaves. Date of symptom expression was recorded as days after emergence (DAE). In Expt. 2,height measurements were taken when each plant first reached stage 3 symptoms.

The inbreds that showed differences in the field also were tested in pot experiments in the greenhouse. The trial was arranged in a randomized complete block design with 12 replications per line. Plastic pots (1.8 liter) were filled with Spinks sandy loam soil (Psammentic Hapludalfs) to the desired height for placing the herbicide band $19 \mathrm{~cm}$ from the top. A 20$\mathrm{ml}$ aliquot of herbicide solution (sufficient volume to provide a thin, even layer over the soil surface) was applied by syringe at a rate equivalent to $1 \mathrm{~kg} \cdot \mathrm{ha}^{-1}$ before the remainder of the pot was filled. Two cucumber seeds were planted in each pot; the seedlings were thinned to one per pot. When the leaves showed stage 2 symptoms, plant height was measured. The plants then were removed from the pots and the soil washed gently from the roots using a kitchen hose sprayer. Tap root length was measured immediately; the roots were airdried at room temperature (20 to $25 \mathrm{C})$ to obtain dry weights. Date of symptom expression was expressed as DAE.

Significant differences among lines were observed for time-to-symptom expression in both field trials (analysis of variance $P \leq 0.05$; Table 1). The time-to-symptom expression for the first experiment was, on average, $\approx 8$ days shorter than for the second, which is most likely due to the warmer, drier, sunnier weather in the first half of the summer. Such conditions would lead to more rapid growth overall, higher transpiration rates, and more optimal conditions for herbicide damage symptom development. A similar effect also has been noted in the greenhouse, where a shorter time-to-symptom expression was recorded during sunny than during cloudy weather (Grumet et al., 1992).

The effect of the determinate allele on shoot growth was readily apparent in three of the four genetic backgrounds (Table 1). In each of those cases, plants containing the $d e$ allele were significantly shorter when they reached stage 3 symptom expression than were their-De counterparts. Thus, at a time when the roots were presumably of comparable length, the shoot height differed. The exception was in

Table 1. Height of plants at stage 3 herbicide damage symptom expression and percentage of plants showing symptoms in the field at 18 (Expt. 1) or 26 (Expt. 2) days after emergence (DAE).

\begin{tabular}{|c|c|c|c|c|}
\hline \multirow[b]{2}{*}{ Cultigen } & \multirow[b]{2}{*}{$\begin{array}{l}\text { Growth } \\
\text { habit }^{y}\end{array}$} & \multirow{2}{*}{$\begin{array}{l}\text { Mean ht }(\mathrm{cm}) \text { at } \\
\text { stage } 3 \text { symptoms } \\
\text { Expt. } 2\end{array}$} & \multicolumn{2}{|c|}{$\begin{array}{c}\text { Plants showing } \\
\text { stage } 3 \text { symptoms }(\%)^{2}\end{array}$} \\
\hline & & & $\begin{array}{l}\text { Expt. } 1 \\
18 \text { DAE }\end{array}$ & $\begin{array}{l}\text { Expt. } 2 \\
26 \text { DAE }\end{array}$ \\
\hline Marketmore 76 & De & $16.6^{* *}$ & $28 b^{x}$ & $50.7 \mathrm{~d}^{\mathrm{x}}$ \\
\hline Marketmore 86 & de & 11.5 & $26 \mathrm{bc}$ & $43.3 \mathrm{~d}$ \\
\hline Addis & $\mathrm{De}$ & $15.4^{* *}$ & $34 \mathrm{c}$ & $32.0 \mathrm{bc}$ \\
\hline Clinton & De & $16.2^{* *}$ & $14 \mathrm{ab}$ & $25.3 \mathrm{~b}$ \\
\hline M21 & de & 6.5 & $7 a$ & $10.7 \mathrm{a}$ \\
\hline M27 & de & 7.6 & $29 \mathrm{bc}$ & $44.3 \mathrm{~d}$ \\
\hline WI 6373 & $\mathrm{De}$ & 11.4 & $17 \mathrm{abc}$ & $4.7 \mathrm{a}$ \\
\hline WI 6375 & de & 9.7 & $53 \mathrm{~d}$ & $36.7 \mathrm{~cd}$ \\
\hline Fancipak & De & 13.3 & --- & $67.7 \mathrm{e}$ \\
\hline
\end{tabular}

${ }^{2}$ Stage 3 symptoms $=$ necrotic lesions on leaves.

${ }^{y} \mathrm{D} e=$ indeterminate; $d e=$ determinate.

${ }^{x}$ Values within a column followed by different letters are significantly different by. $\mathrm{LSD}, \mathrm{P}=0.05$. $\mathrm{LSD}_{0.05}=$ 17 for Expt. 1; LsD $_{0.05}=11.8$ for Expt. 2.

${ }^{* *}$ Significantly different from the determinate members of the pair or group by $t$ test at $P=0.01$. 
Table 2. Days after emergence (DAE) to herbicide damage symptom expression in the greenhouse (GH) and field. Mean plant height, root length, and root mass at stage 2 symptom appearance in the GH.

\begin{tabular}{|c|c|c|c|c|c|c|}
\hline \multirow[b]{2}{*}{ Line } & \multirow[b]{2}{*}{$\begin{array}{l}\text { Growth } \\
\text { habit }^{2}\end{array}$} & \multicolumn{2}{|c|}{ DAE } & \multicolumn{3}{|c|}{ Stage 2} \\
\hline & & $\begin{array}{c}\text { Field } \\
\text { Stage } 3^{\mathrm{Y}}\end{array}$ & $\begin{array}{c}\text { GH } \\
\text { Stage } 2\end{array}$ & $\begin{array}{l}\mathrm{Ht}(\mathrm{cm}) \\
\text { in } \mathrm{GH}\end{array}$ & $\begin{array}{l}\text { Root length } \\
(\mathrm{cm}) \text { in } \mathrm{GH}\end{array}$ & $\begin{array}{c}\text { Root mass } \\
\text { (mg) }\end{array}$ \\
\hline Addis & $D e$ & $20 a b^{x}$ & $22 a^{x}$ & $6.7 b^{x}$ & 33.3 & 73 \\
\hline Clinton & $D e$ & $23 \mathrm{bc}$ & $26 \mathrm{C}$ & $6.8 \mathrm{~b}$ & 32.4 & 57 \\
\hline M21 & $d e$ & $25 \mathrm{C}$ & $25 \mathrm{bc}$ & $6.1 \mathrm{ab}$ & 31.1 & 89 \\
\hline M27 & de & $18 \mathrm{a}$ & $22 \mathrm{a}$ & $4.9 \mathrm{a}$ & 33.0 & 64 \\
\hline WI 6373 & $D e$ & $20 \mathrm{ab}$ & $26 \mathrm{C}$ & $7.5 \mathrm{~b}$ & 30.6 & 53 \\
\hline WI 6375 & $d e$ & $18 \mathrm{a}$ & $23 \mathrm{ab}$ & $4.8 \mathrm{a}$ & 32.6 & 46 \\
\hline \multicolumn{2}{|c|}{$\operatorname{LSD}(P=0.05)$} & 4.3 & 2.7 & 1.6 & & \\
\hline \multicolumn{2}{|l|}{$\mathrm{MS}_{\mathrm{G}} / \mathrm{MS}_{\mathrm{E}}{ }^{\mathrm{w}}$} & $22.6 / 9.3$ & $31.1 / 15.7$ & $14.6 / 5.9$ & $13.9 / 31.1$ & $3.02 / 3.23$ \\
\hline \multicolumn{2}{|c|}{ ANOVA $P$ value } & 0.05 & 0.10 & 0.05 & & NS \\
\hline \multirow[t]{2}{*}{ Mean } & $D e$ & 21.0 & 24.7 & $7.0^{* *}$ & 32.1 & 61 \\
\hline & $d e$ & 20.3 & 23.3 & 5.3 & 32.2 & 66 \\
\hline \multicolumn{2}{|l|}{$\mathrm{MS}_{\mathrm{De}}{ }^{\mathrm{v} / \mathrm{MS}_{E}}$} & $10.7 / 9.3$ & $29.3 / 15.7$ & $54.1 / 5.9$ & -- & --- \\
\hline
\end{tabular}

$D e=$ indeterminate; $d e=$ determinate.

${ }^{y}$ Days to $50 \%$ of the plants in the plot showing stage 3 symptoms in field Expt. 1.

${ }^{x}$ Values within a column followed by different letters are significantly different by LSD, $P=0.05$.

'MS. = mean square genotype; MS. = mean square error from analysis of variance (ANOVA).

$\mathbf{r}^{\mathbf{M S}} \mathbf{S}_{\mathbf{e}}=$ mean square for orthogonal contrast, determinate vs. indeterminate.

${ }^{* *}$ Indeterminate genotypes significantly different from the determinate genotypes by orthogonal contrast, $\mathrm{P}$ $=0.01$.

In the little-leaf pair, the determinate trait once again was associated with faster root growth (fewer days to symptom expression).

There were no significant differences among lines for root length or mass at stage 2 symptom expression, nor did the determinate and indeterminate genotypes differ from each other as a group for root length or mass at this time (Table 2). These results indicate that the herbicide banding data signified root growth rate rather than differences in herbicide sensitivity. If the latter had been the case, symptoms would be expected to appear sooner, even though the roots had not grown as much. There also was no correlation between shoot height and root length ( $r=-0.36$, nonsignificant). There was, however, a negative correlation between root length and DAE to stage 2 symptoms $(r=-0.81 ; P<0.05)$; i.e., those lines that took longer to reach stage 2 tended to have shorter, slower-growing roots.
Overall, there was no difference in root growth rate between the determinate and indeterminate members of the near-isogenic 'Marketmore 76'-'Marketmore 86' pair, but there were differences for the other determinate-indeterminate comparisons. The apparent effect of the determinate gene, however, varied with genetic background. In two cases, the herbicide damage symptoms appeared earlier in the plants with the determinate allele, and in one case, they appeared later. Thus, the observed differences in root growth rate were likely due to factors other than the determinate allele.

\section{Literature Cited}

Delaney, D.E. and R.L. Lower. 1984. Effects of the determinate locus on number of lateral branches in crosses between four cucumber lines and Cucumis sativus var. hardwickii. Cucurbit Genet. CoOP. Rpt. 7:3-5.
Delaney, D.E. and R.L. Lower. 1985. Segregation of the determinate (de) allele in crosses between Cucumis sativus L. and C. sativus var. hardwickii R. Cucurbit Genet. Coop. Rpt. 8:2-3.

Delaney, D.E. and R.L. Lower. 1987. Generation means analysis of plant characters in crosses between two determinate cucumber lines and Cucumis sativus var. hardwickii. J. Amer. Soc. Hort. Sci. 112:707-711.

Denna, D.W. 1971. Expression of determinate habit in cucumbers. J. Amer. Soc. Hort. Sci. 96:277279.

George, W.L. 1970. Genetic and environmental modification of determinate plant habit in cucumbers. J. Amer. Soc. Hort. Sci. 95:583-586.

Goode, M.J., J.L. Bowers, and A. Bassi. 1980. Little-leaf, a new kind of pickling cucumber plant. Ark. Farm Res. 29:4.

Grumet, R., M. Barczak, C. Tabaka, and R. Duvall. 1992. Above-ground screening for genotypic differences in cucumber root growth in the greenhouse and field. J. Amer. Soc. Hort. Sci. 117:1006-1011.

Munger, H.M. 1985. Near-isogenic lines of several cucumber varieties. Cucurbit Genet. Coop. Rpt. $8: 4-6$.

Pierce, L.K. and T.C. Wehner. 1990. Review of genes and linkage groups in cucumber. HortScience 25:605-615.

Prend, J. and C.A. John. 1976. Improvement of pickling cucumber with the determinate (de) gene. HortScience 11:427428.

Ramirez, D.R., T.C. Wehner, and C.H. Miller. 1988. Growth analysis of three cucumber lines differing in plant habit. HortScience 23: 145-148.

Temple, P.J. 1990. Growth form and yield responses of four cotton cultivars to ozone. Agron. J. 82:1045-1050.

Tigchelaar, E.C. 1991. New vegetable variety list 23. HortScience 26:343-357.

Wehner, T.C. and C.H. Miller. 1987. Optimum plant density for multiple-harvest yield of determinate and indeterminate cucumbers. Cucurbit Genet. Coop. Rpt. 1029-30.

Wehner, T.C., J.E. Staub, and C.E. Peterson. 1987. Inheritance of little leaf and multibranched plant types in cucumber. Cucurbit Genet. Coop. Rpt. 10:33-34. 